Table 1. EFFFCT OF CURARE ON THE RATE OF 32P-ORTHOPHOSPHATE INCORPORATION. VALUES ARE PRESENTED AS THE SPECIFIC ACTIVITY OF
TISSUE INORGANIC PHOSPHORUS BEING TAKEN AS 100, AND AS THE MEAN OF 'THREE EXPERIMENTS

Specific activities relative to inorganic $P$ of tissue

ATP/IP
ADP/IP
PCP/IP
BP/IP

Control

Curarized

$55 \cdot 3 \pm 3 \cdot 6$
$44 \cdot 1 \pm 2 \cdot 9$

$44 \cdot 1 \pm 2 \cdot 9$

$73 \cdot 5 \pm 9 \cdot 2$
$814 \cdot 2 \pm 17 \cdot 1$

$39 \cdot 2 \pm 3 \cdot 8$

$30 \cdot 4 \pm 1 \cdot 2$

$51 \cdot 3 \pm 16 \cdot 1$

$1,641 \cdot 9 \pm 52 \cdot 9$

ATP, ADP, PCP, BP, IP: Specific activities of adenosine triphosphate adenosine diphosphate, phosphocreatine phosphate, blood inorganic phosphorus, tissue inorganic phosphorus, respectively.

Table 2. Concentration of Adenine nucleotides in Control and CURARIZED GROTP

\begin{tabular}{ccc} 
& \multicolumn{2}{c}{$\begin{array}{c}\text { Micro moles of adenine nucleotides per g of fresh tissue } \\
\text { Control }\end{array}$} \\
Curarized \\
AMP & $0.54 \pm 0 \cdot 14$ & $0 \cdot 58 \pm 0 \cdot 14$ \\
ADP & $1 \cdot 02 \pm 0 \cdot 33$ & $0 \cdot 83 \pm 0 \cdot 34$ \\
ATP & $4.42 \pm 0.72$ & $3 \cdot 44 \pm 0.34$
\end{tabular}

requirement of energy would also be decreased as an example of self-regulation or feedback in a biological system. The little differences in the concentration of adenine phosphates seem to support this view. However, the marked difference in the ratio of specific activity of blood phosphate to inorganic phosphorus of tissue in nurarized muscle suggests that another factor is responsible for the phosphate entry or transport. As the detailed mechanism of the efficient cellular organization for fast resynthesis and recycling of the nucleotide is still obscure, it remains to be established whether somo possible changes in the membrane permeability by curare-receptor com. plexes have some effect on this slowing down of high energy phosphates.

I thank Prof. G. Favilli, Dr. C. Cessi and Dr. E. Fadiga for their advice.

Institute of General Pathology,

S. K. JUHN

University of Bologna,

Bologna, Italy.

${ }^{2}$ Carafoli, E., Margreth, A., and Buffa, P., Nature, 196, 1101 (1962).

${ }^{2}$ Cessi, C., and Buffa, P., Lo Sperimentale, 113, 1 (1963).

${ }^{3}$ Bovet, D., Bovet-Nitti, F., and Marini-Bettolo, G. B., Curare and Curare like Agents (Elsevier Publishing Co., 1959)

4 Ephrenpreis, S., Biorhim. Biophys. Acta, 44, 561 (1960).

Buffa, P., Azzone, G. F., Carafoli, E., and Muscatello, U., I.o Sperimentale, 110, 79 (1960).

' Hurlbert, R. B., Schmitz, H., Brumm, A. F., and Potter, V. R., J. Biol. Chem., 209, 23 (1954).

'Martin, G. B., and Doty, D. M., Anal. Chem., 21, 956 (1949).

\section{Two-dimensional Separation of Nucleic Acid Bases on Cellulose Layers}

THIN-LAYER chromatography on cellulose layers has been shown to be an effective method for separation and quantitative determination of nucleic acid bases, nucleosides and nucleotides ${ }^{1-5}$ which has considerable advantages over paper chromatography. Keck and Hagen ${ }^{\overline{5}}$ recently reported a one-dimensional thin-layer chromatographic separation of the four major bases of RNA and DNA. The present communication describes a twodimensional procedure which in this laboratory has proved useful for separating more complex mixtures of nucleic acid bases.

Preparation of cellulose layers. $20 \mathrm{~g}$ cellulose powder MN 300 (Macherey and Nagel, Düren, Germany) are suspended in 120-130 ml. distilled water, homogenized in a Waring blender for 15-20 sec, and coated on degreased. glass plates in the usual way, using a StahI-type applicator $^{6}$ adjusted to a slit width of $0.5 \mathrm{~mm}$ (Desaga, Heidelberg, Germany). The plates are allowed to dry at room tomperature for $10-15 \mathrm{~h}$.

Chromatographic procedure. Chromatography is carried out in closed rectangular jars filled with solvent to a height of about $0.8 \mathrm{~cm}$. It is not necessary to saturate the tank atmosphere with solvent vapours. Solvents used are: (1) methanol/concentrated hydrochloric acid/water $(70: 20: 10, \mathrm{v} / \mathrm{v})$, for the first dimension; (2) $n$-butanol/

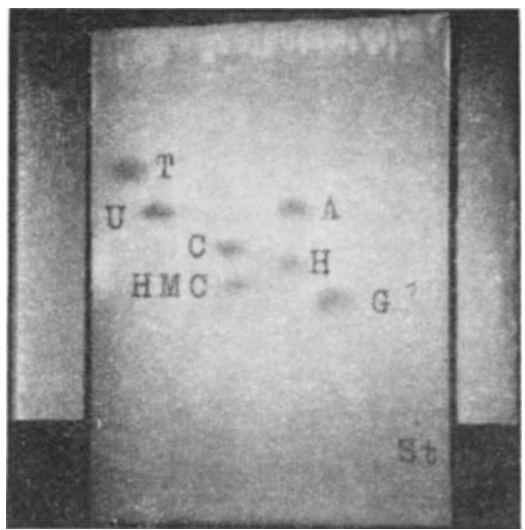
Fig. 1. Two-dimensional separation of nucleic acid bases on a $0.5 \mathrm{~mm}-$ in ten $1 \mu \mathrm{l}$.-portions to the start spot St. Solvents: see text. First dimenin ten $1 \mu$.-portions to the start spot st. Solvents: see text. First dimenment distances: $10 \mathrm{~cm}$ in either direction. The black areas of the photograph are parts of the layer which were removed before the second development. Total development time: about 150 min. $T=$ thymine; $U=$ uracil; $C=$ cytosine; $H M C=5$-hydroxy-methyl cytosine; $A=$ adenine; $H=$ hypoxanthine; $G=$ guanine. (Photography in short-wave ultra-violet light)

methanol/water/concentrated ammonium hydroxido (60 : $20: 20: 1, v / v)$, for the second dimension. The plate is dried between the two developments for 3-5 min in a current of cold air, then for 5 min in a current of hot air $\left(60^{\circ}-70^{\circ} \mathrm{C}\right)$ in order to remove hydrochloric acid as completely as possible.

Fig. I shows a separation of a mixture of bases. The main advantages of this method are its speed, sensitivity and sharpness of resolution.

This work was supported by grants-in-aid from the U.S. Atomic Energy Commission, the U.S. Public Health Service, the National Science Foundation, and the Burroughs Wellcome Fund.

\section{K. RANDERATH}

Biochemical Research Laboratory and John Collins Warren Laboratories of the Huntington Memorial Hospital of Harvard University,

Massachusetts General Hospital, Boston 14, Mass.

1 Randerath, K., and Struck, H., J. Chromatogr., 6, 365 (1961). 2 Randerath, K., Biochem. Biophys. Res. Comm., 6, 452 (1961).

3 Josefsson, L., Biochim. Biophys. Acta, 72, 123 (1962).

${ }^{4}$ Chmielewicz, Z. F., and Acara, M., Anal. Biochem., 9, 94 (1964).

Keck, K., and Hagen, U., Bicchim. Biophys. Acta, 87, 685 (1964),

- Stahl, E., Chemiker Z., 82, 323 (1958).

\section{Carbonyl Chloride Cycle in Uraemia}

THe role of carbonyl chloride in the production of uraemic coma has been emphasized in previous publications ${ }^{1,2}$. It has been further demonstrated that urea reacting with ammonium chlorido in vivo produces carbonyl chloride with the liberation of ammonia. In view of the enormous number of cases of uraemia already handled by the author it appears that a plausible suggestion with regard to the biochemical steps involved in the production of carbonyl chloride and associated compounds is called for.

Urea is formed in the liver in the cycle described by $\mathrm{Krebs}^{3}$, involving tho mediation of arginase. In the production of uraemic coma the conversion of urea to carbonyl chloride is involved ${ }^{2}$. The intermediate steps may be outlined as follows:

In the first stage of the reaction one molecule of urea reacts with two molecules of free chlorine $\left(\mathrm{Cl}^{\prime}\right)$ to produce carbonyl chloride and $2 \mathrm{NH}_{2}$. Further reaction with two molecules of free sodium $\left(\mathrm{Na}^{+}\right)$results in two molecules of sodium amide in addition to the carbonyl chloride already existing. Finally, reaction with two molecules of water yields free ammonia and two molecules of sodium 